\title{
CULTURAL TERRITORIALIZATION: THE CASE OF GRAND DUCHY OF LITHUANIA ${ }^{1}$
}

\author{
Tomas Kačerauskas \\ Vilnius Gediminas Technical University, \\ Department of Philosophy and Political Theory, \\ Saulètekio al. 11, LT-10223 Vilnius, Lithuania \\ E-mail: tomas.kacerauskas@vgtu.It
}

The article deals with the dialectics of territorialization, deterritorialization and reterritorialization in the context of cultural regionalistics. The author shows how changing the roles between these modes of terra dynamics influences the becoming of culture interpreted as existential creation. Grand Duchy of Lithuania (GDL) has been used as the case for the development of these ideas in the paper. According to the author, we deal with the polyphonic process of territorialization while the physical aspect serves as a background for cultural deterritorialization and vice versa. The perspective of cultural regionalistics presupposes an existential approach (culture as existential creation), as well as border discourse, while border has been interpreted as cultural phenomenon to be cultivated by both an individual and the nation. The major thesis is the following: the very dynamism of life-world's borders follows from human existential creativity, the source of which is being towards death. The minor thesis: a nation is alive as a terra for individual (re)birth while he (she) creates the future community by his (her) activity. The author presents two kinds of communication during territorialization: horizontal, which deals with realization of a utopia, and vertical, which deals with the myths of the nation's past. The change of roles between different aspects of human terra signifies not linear multi-layered development of culture as a fight for creative space or existential territory. According to the author, reterritorialization presupposes a temporal aspect, which regards all three modes because of dialectics between them. Historical images have been used in our political terra and, vice versa, historical terrae have been understood in political perspective.

Keywords: borders, cultural territory, existential creativity, historical images, modes of territorialization.

doi:10.3846/limes.2010.04

\section{Introduction}

The border discourse deals with different modes of territorialization. The border between the territories is a dynamic phenomenon playing role in our public life-world. As such, the life-world being social is also the historical one. Imagined history of a nation as social body with its borders is playing crucial role in formatting a certain

\footnotetext{
1 The preparing of the article has been supported by COST Action IS0803.
} 
territory as a living space for a community that searches for its identity. Physical territory possessed by a nation with certain sovereignty is only an outcome of this cultural dynamism. That is why I shall concentrate my attention on cultural territorialization including social, political and historical one. In order to avoid only physical connotations of territorialization I shall use the Latin term terra. On the other hand, every movement towards the imagined identity has been accompanied by certain deterritorialization as a loss of some cultural terrae. Additionally, physical territorialization could be accompanied by cultural deterritorialization and vice versa. As a result, we deal with the polyphonic process of (de)territorialization while phonics of physical territorialization serves as a background for cultural deterritorialization and vice versa. What is more, we have role changes between both these two sources of terra's dynamism and different planes of terra's semantic fields.

GDL being an empire with all phases of rise and collapse is not only a case of (de) territorialization. On the one hand, we have a kind of deterritorialization while several contemporary nations claim to the heritage of GDL. On the other hand, GDL has been until now a source of a common social body divided by new political borders. As such GDL has been a vector for identity beyond the territory of Central Europe as a part of European Union (EU) with fixed space. In this way, the imagined GDL is playing a role of Promised Land, i.e. of future reterritorialization. Every re-activity is possible only as a co-activity in common historical life-world and presupposes creativity instead of repetition. Re-establishment of terra means creation of new kind of coexistence despite public relationship inside a political territory. What is more, a new terra to be re-established claims as well the established territory and presupposes a phonetics of a-scholia or disquiet in our public life as inspired background for our existence.

Therefore, there are at least three modes of terra dynamics: territorialization, deterritorialization and reterritorialization. The very dynamism of life-world's borders follows from human existential creativity, the source of which is being towards death. The latter includes not only coexistence but also analogy between being of an individual and being of the nation. We can speak about mortality of a nation from the perspective of (de)(re)territorialization. Every nation exists thanks to borders' dynamism, which could be secured not only by extending them but also by the change of the role between their different planes. The most significant periods of nation's existence are namely those of cultural (re)territorialisation, usually accompanied by physical deterritorialization. Existential discourse presupposes, as well, the change of role between an individual and his (her) nation. On the one hand, an individual exists only as participant of the nation created by him. His activity inspired by his being towards death is possible only in national terra as existential environment to be extended. On the other hand, every nation exists while only being imagined as a community for coexistence of its individuals. A nation is alive as a terra for individual (re)birth while he (she) creates by his (her) activity the future community.

GDL is not only a case for developing the mentioned ideas. This multicultural historical community plays important role in regional studies, which should be developed 
first of all as cultural regionalistics including both existential analytics and cultural phenomenology. The phenomena are individual only when being regional and culture is creative only when existential. In this way I shall interpret GDL as paradigm of (de) (re)territorialization. However, this perspective needs firstly to analyse GDL as an empire with its phases of borders' increase and decrease ("GDL as empire”). The question of reterritorialization will be analysed in the chapter "Past and future of GDL".

\section{GDL as empire}

GDL emerged in 13th century as a counter-power to Teutonic Order established recently in the region and as an expansive power towards the territory weakened after invasion of Mongols-Tatars ${ }^{2}$. The constant tension in the West searching for the alternative resources in the East has been a successful formula for the increase of this empire. Rephrasing Arnold Toynbee (Тойнби 1991), who had used the case of GDL to support his challenge-response theory ${ }^{3}$, all a rising empire needs is war, i.e. the threat of being destroyed. The perspective of death is one of the sources of analogy between an individual and the nation. Within an empire we deal with a specific nation, which is both more imagined and more real than any homogeneous nation. An empire nation is more imagined being directed by a ruler despite the cultural differences between the communities inside a state. On the other hand, it is more real because of territory occupied by this nation. The territorialization covered its other modes does play here the role of realization. We shall see how territorialization, deterritorialization and reterritorialization, by changing their roles in different cultural planes, make certain life-world, which has been created together with our existential project, real.

In two hundred years after the establishment of the state of "land-Vikings" 4 the territory of GDL has increased from 100 thousand sq. km. to 1 million sq. km., i.e. 4,5 thousand sq. $\mathrm{km}$. every year on the average. It is so-called explosive expansion of an empire that has its prize. Zenonas Norkus shows that explosive expansion of an empire overloads the centre with information that enables to be worked out, as well as presupposes communicative disturbance that leads finally to decentralization (Norkus 2007: 37). Territorialization means rather assimilation than occupation in the perspective of terra concept while deterritorialization refers to cultural loss instead of decentralization of power. On the other hand, we deal with certain centralization during reterritorialization as an attempt to re-establish a political body under the influence of nostalgia for empire.

In this way we have a case of a territorialization accompanied with a process of deterritorialization not only in physical plane. On the one hand, we have to do with

\footnotetext{
2 According to Lithuanian historicist Edvardas Gudavičius, the Lithuanians were the jackals that followed after Mongol tiger.

${ }^{3}$ More about it see Kačerauskas 2008a.

4 The term used by Alfredas Bumblauskas (Bumblauskas 2005).
} 
a formation of historical nation, called Lithuanian nation (litvin ${ }^{5}$ ), which included Ruthenian, i.e. East-Slavic sub-nations (contemporary Belarusian, Ukrainian and partly Russian) ${ }^{6}$. GDL became a very serious competitor to Moscow in the consolidation of Russian terrae. This consolidation had been declared as political aim by both Great Duke of Lithuania Algirdas (1344-1377) and Vytautas the Great (1392-1430). On the other hand, the consequence of this territorialization has become deterritorialization of the very Lithuanian terra with its own culture including (Baltic) language and (pagan) religion. During the pick of GDL's increasing the ethnical Lithuanian territory covered only 10 percents of the whole empire, while Lithuanian speakers covered only 20 percents of the whole population. As a result, we have a case of deterritorialization, i.e. laundering or assimilation of Lithuanian ethnos with the Slavic one. Thus, we have a case of Francs in Gallia. The great dukes from the very beginning having been bilingual became one-lingual to the prejudice of the Lithuanian language.

There are typical stages of empire's development during more than 500 years of GDL's existing: explosive rise (up to the death of Vytautas the Great 1430), stabilization (1430-1492), decline (1492-1506), renaissance of rise (joining of Livonia 1559), repeated decline (2nd half of 17 th century), temporal stabilization (1674-1772), irreversible collapse (1772-1795). This development of the empire had been not linear: the period of decline had been accompanied by cultural rise, temporal stabilization had continued for almost one hundred years and irreversible collapse followed the innovative reforms in social, political and cultural life. The Commission of Education (1773) and Constitution of 3rd May (1791) are to be mentioned. Additionally, resistance to collapse $^{7}$ has become a heroic paradigm that inspired the coming resistances both in inherited (spirit of empire) and new (national) communities for ages. Heroic paradigm to be formatted in certain life-world with public expectations refers to reterritorialization that is no way reconstruction of previous empire. Firstly, such reconstruction is impossible after losing terra of empire as a cultural whole in a new existential situation. Secondly, reterritorialization has to do rather with cultural revival that is possible in a new political situs. As such, it is neither reconstruction nor repetition.

I would rather use the concept "change of roles", developed by Michail Bakhtin (Бахтин 2000) in the interconnection between author and hero, instead of the concept "clash of civilizations" (Huntington 1996) for the analysis of territorialization including the mentioned modes. Firstly, historical discourse, inseparable from border's discourse, presupposes certain heroes. Secondly, the all modes of territorialization have to do with the heroes who emerge in certain narration following from our life-world. Last but not least, the analogy between the individual and the nation allows speaking even about a nation as a tragic hero to be narrated by an individual. In this way the interconnection between the author and the hero is a source of analogy that should be

\footnotetext{
${ }^{5}$ Not by accident, the alternative name of the new nation has been used in the Ruthenian language.

${ }^{6}$ It should be noticed that the Lithuanian language is not Slavic.

${ }^{7}$ Rising of Tadeusz Kościuszko.
} 
interpreted as a mutual participation in transferring our life borders instead of only functional similarity. The different modes of territorialization having the vertical and horizontal dimensions on the cultural map presuppose space for changing their roles. This cultural dynamism corresponds to our existential activity while creating life story.

The perspective of the death, having in mind both an individual and his (her) nation, does not close our cultural space; on the contrary, it inspires our creativeness, the seeds of which take part in other narrations even after our death ${ }^{8}$. That is why the culture to be interpreted as existential creation and cultural map has to do with life borders including their historical and social aspects. The individual life borders convergent with life borders of his (her) nation acquiring existential space while communicating with the heroes of historical communities. In this way, coexistence covers both horizontal communication in territorialization of a utopia and vertical communication in reterritorialization of the myths. The deterritorialization would play here the role of epoche using phenomenological terms, i.e. a kind of transferring from territorialization to reterritorialization and, vice versa, after suspending both of them. Later I shall analyse the dialectics of territorialization, deterritorialization, and reterritorialization in contemporary cultural space of the region. Now we should come back to our historical case because of moving without any support of empirical material (as a kind of infantry) in risky way too far in unknown terra.

The history of GDL is very illustrative: the periods of territorial declines in a physical sense are significant with the rise of cultural terra. That is the case of Alexander's period (1492-1506) to be connected not only with the extension of writing culture (Lithuanian Metrica) and development of magnificent architecture (Saint Anna's church, reconstruction of Rulers' palace, the wall of Vilnius city) but also with the beginning of professional philosophy in Lithuania ${ }^{9}$. Writing, building and philosophising are three cultural dimensions that intersect all three modes of territorialization. On the one hand, we can speak about certain terrae in arts (technai) of such human activities as writing, building and philosophising. These arts are developed as ability to transfer the existential borders keeping the ethical limits. Creative breaking of borders keeping certain limits characterises the very art of life as an ability to move to unknown land, i.e. a kind of cultural territorialization. Using our metaphors of building we can interpret Saint Anna's church as vertical dimension of novelty in city's narrative while the wall corresponds to horizontal limits of tradition. The city wall serves as guaranty of safety (defending from enemies) and order (defending from free migration of people, commodities and finances). The Rulers' palace being a fort and a source of national development inseparable from historical memory includes both mentioned functions. Building is a kind of writing on urban terra, which has been territorialized,

\footnotetext{
${ }^{8}$ More about it see Kačerauskas 2009a.

${ }^{9}$ According to Romanas Plečkaitis, the professional philosophy in Lithuania started in 1507, after establishing Dominican particular school founded by Alexander (Plečkaitis 2009).
} 
deterritorialized and reterritorialized by every generation. Philosophy as an art of life (techne ton bion $)^{10}$ has to do with every art including building and writing while they being analogical take part in existential creation. In existential space the arts intersect each other creating new cultural territories to be fortificated.

As it was mentioned, we can notice a similar change of the territorialization's modes in the last period of GDL's “irreversible collapse”. Thus, the explosive rise of physical terra could be accompanied with the loss of the cultural one and, vice versa, the collapse of physical terra could initiate a revival and extent of the cultural one. The change of roles between different aspects of human terra signifies not linear multi-layered development of culture as a fight for creative space or existential territory. Commission of Education opened a new ethical terra connected with enlightened, i.e. cultivated, being. Similarly, Constitution of 3rd May opened a new public coexistence to be fortified as legal order ${ }^{11}$. In paradoxical way the latter territorialization provoked disorder (confederations of Vilnius and Targovica) and finally the loss of national terra (deterritorialization). However, reterritorialization allows interpreting Constitution of 3rd May as a source of our public terra during the coming ages.

Despite public integration in historical GDL, the concept of nation opens different perspectives and consequently different reterritorializations of this promised terra for such "imagined communities" as nations emerged at least two hundred years after the collapse of this empire. The mentioned processes of territorialization within GDL could be traced as well as a source for the becoming of such nations as the Belarusian and Ukrainian ones. What is more, we can notice some kind of nostalgia for former empire, nostalgia connected with aspirations of these nations to enter European terra imagined as a kind of paradise.

\section{Past and future of GDL}

Reterritorialization presupposes a temporal aspect, which regards all three modes because of dialectics between them. Firstly, evolution of an empire treated as the competition between territorialisation's modes for the domination needs historical (temporal) approach. Secondly, the concept of the role change includes the terms of space and time in a double sense: every change needs some space and time, beside this space and time could also change their role. Thirdly, analogy between a mortal individual and the nation opens a death's perspective that could be a source for creative aspirations inseparable from existence as development of life's art. Finally, the other side of every dynamic, creative and innovative process emerged as phenomenon of coexistence, is temporality.

10 More about philosophy as art of life see Kačerauskas 2008 b.

${ }^{11}$ Change of the roles in the context of territorialization presupposes some paradoxes. One of them is the following: such hero of one public event (Commission of Education) as Ignas Jokūbas Masalskis emerges as antihero of another one (Kościuszko's rising followed from Constitution of 3rd May). 
As a subject of reterritorialization, GDL is both a gold past and imagined future for new national societies ${ }^{12}$. Let us consider Belarus as one of such societies. On the one hand, GDL is a factor of Belarusian nation's formation searching for different from Russia historical sources. Every historical discourse is a part of cultural territorialization inseparable from certain relationship between centre and periphery: historical imagination both follows and forms gravitation to national community, which is always historical. After inherited GDL as research subject Belarusian historicists defined their discourse as very different from Russian because of historical hostility between Lithuanian and Russian empires as competitors in the historical fight for territories. In other words, Belarusian historicists have defined a different cultural terra separated from the Russian one. The border of this terra, on the other hand, is not so clear because of belonging of Belarusian society to both GDL and Central Europe, a part of which GDL had been for ages. This ambivalent territorialization mirrors the change of role between centre and periphery: a new nation needs new centre for terra's defining but it needs also belonging to the other centre for its coexistence. As a result, a theory of Slavic element being essential during GDL's time emerged in Belarusian historiography (Пашкоу 2007). The writing culture of GDL in Ruthenian as old Belarusian (Lithuanian chronicles, Lithuanian Metrica, Lithuanian Statut) purportedly is crucial. This theory emerged in the context of deficit of Belarusian language in public space of contemporary Belarus and could be interpreted as a kind of reterritorialization in order to support national feelings ${ }^{13}$. The biggest danger for the development of this theory comes not from Lithuanian (as direct inheritors) side $^{14}$, but from the side of another new nation, i.e. Ukrainian as another GDL's inheritor who claims this heritage for similar reason ${ }^{15}$.

Writing as a kind of art of coexistence to be developed by every nation is inseparable from dialectics of territorialization's modes. Writing in Old Russian (Ruthenian) in order to establish Lithuanian cultural terra had been ambivalent from the very beginning. After entering the space of Christian life-world in 1387 Lithuanian culture has assumed new features including the traditions of writing ${ }^{16}$. Because of imperial politics the tradition of writing (and monks-writers) came from Russian terra while the first written records (Lithuanian chronicles) had been used for inscription of Lithuanian ruler's dynasty into the community of European rulers (Palemonas

\footnotetext{
12 I mean Belarus and in a smaller extent Ukraine. What concerns modern Lithuania, reterritorialization of GDL had been important here in the second half of 19th century. The modern and postmodern society could be defined following this criterion if postmodernity did not cover all modes of territorialization. As a result, we can treat the dialectics of territorialization's mode as postmodern approach.

13 The historical discourse has been developed usually in Belarusian not only because of the role of history in national becoming but also because of cultural borders (territorialization) to be established between Belarusian and Russian cultures.

14 There is a number of lithuanisms in this one of the writing languages of GDL (beside Latin).

15 Sее Бумблаускас 2008.

16 Beside the new written tradition, oral culture has been developed for hundred years.
} 
myth) ${ }^{17}$. The Ruthenian language, serving Lithuanian ideology, has been a source of cultural territorialization: on the one hand, "Lithuanian" writings needed translation into Russian for publishing in Russia; on the other hand, it played the role of Lithuanian separatism after Lublin union at least for 130 years. In this way writing in Ruthenian had been an important art that signified both territorialization and deterritorialization of Lithuanian life.

GDL is a source of belonging to Central Europe open to Western cultural terra, which has specific historical development. In this way GDL is not only a historical heritage of former empire to be shared between modern nations ${ }^{18}$. GDL has become also a territory of a common future in a region imagined as Central Europe ${ }^{19}$. In other words, historical memory that is inseparable from public imagination nurtures a kind of cultural terra open to all three modes of territorialization. Additionally, Central Europe as an imagined region and an "anti-Europe" (Delanty 2002) is possible thanks to historical images taking part in our political aspirations. GDL as a rim of Central Europe had been the very centre of fight for European spiritual terra to be cultivated ${ }^{20}$. In this way, we have a culture inseparable from communication between the generations. We deal with a kind of communication, which is not only historical. Historical images have been used in our political terra and vice versa historical terrae have been understood in political perspective. During every communication as a public action, our spiritual terra loses some borders to be understood, i.e. covered by one's hermeneutic circle that is inevitably political and historical. This hermeneutic deterritorialization follows our searching for own terra as a background for identity being cultivated, i.e. from the very territorialization that could be considered as existential. It could be said about both individual and social identity, whereas an individual and his community interact changing their roles. A terra of a national community, which includes the imagined historical heroes, appears as environment for individual existence while cultivating this terra in a certain way of (de)(re)territorialization.

\section{Instead of conclusions: new situs of territorialization}

Nowadays we have another situation of (de)(re)territorialization. Situs corresponds to a certain living environment that covers both historical imagination and future aspirations. On the one hand, there are no more borders between Lithuanian and Polish terrae. However, this deterritorialization follows historical precedent of a deterritorialization inside Rzeczpospolita as Republic of Both Nations, i.e. historical precedent of political Union. On the other hand, we have a kind of territorialization between such new political body as EU and such "anti-European” country as Belarus. Once again,

\footnotetext{
17 This inscription as a kind of claim was very successful: in one hundred years the same Lithuanian dynasty ruled not only Lithuania (including Belarus and Ukraine), but also Poland, Hungary and Czech.

${ }^{18}$ For instance, Belarus had laid claim to GDL's (Jogaila's) blazon.

19 More about Central Europe from the perspective of cultural regionalistics see Sadowski 2009.

${ }^{20}$ More about it see Kačerauskas 2009b.
} 
we can question validity of this territorialization, while there had been no border inside integrative society of GDL, image of which has been alive as an integrative factor in the different sides of the border until now (reterritorialization). In this way GDL is both a precedent of (de)(re)territorialization and a source for cultural terra on both sides of the border to be transferred for the sake of our existential creation. We deal with reterritorialization while empire is a source for nation's formatting.

I shall finish with the following questions: What role does nostalgia of an empire in formatting of a nation play? In what way could a historical image become a political factor of a nation's future? What role does historical imagination in our existential creation play? Whether and how territorialization, deterritorialization and reterritorialization changing their roles influence our identity? What aspects of transferring the borders there are in culture as cultivating a spiritual terra? What is the connection between the dynamism of territorialization's modes and our life-world to be created by every generation? Could we speak about the change of roles between different territorialization's modes as a source for changing our historical situs? What borders does this change have? What are the borders of such political body as Central Europe? What is border of border's discourse?

\section{References}

Bumblauskas, A. 2005. Senosios Lietuvos istorija. Vilnius: R. Paknio leidykla.

Delanty, G. 2002. Europos išradimas: idejja, tapatumas, realybè. Vilnius: LRS leidykla.

Gudavičius, E. 1999. Lietuvos istorija nuo seniausiu laiku iki 1569 metu. Vilnius: Lietuvos rašytojų sąjungos leidykla.

Huntington, S. P. 1996. The Clash of Civilizations and Remarking of World Order. New York: Simon \& Schuster.

Kačerauskas, T. 2008a. „Biografija kaip civilizacijos kontrolinis principas: LDK politikos atvejis“, Filosofija. Sociologija 19(3): 72-82.

Kačerauskas, T. 2008b. Tikrove ir kūryba: Kultūros fenomenologijos metmenys. Vilnius: Technika. doi:10.3846/1444-M

Kačerauskas, T. 2009a. "Death in the Perspective of Existential Phenomenology”, Santalka 17(3): 83-91. doi:10.3846/1822-430X.2009.17.3.83-91

Kačerauskas, T. 2009b. "Central Europe as an Imagined Region”, Limes: Cultural Regionalistics 2(2): 106-115. doi:10.3846/2029-0187.2009.2.106-115

Norkus, Z. 2007. „Apie antraji Kijevą, kurio taip ir nebuvo: Lietuvos Didžioji kunigaikštystė lyginamosios istorinès imperijų sociologijos ir tarptautinių santykių teorijos retrospektyvoje“, Politologija 1(45): 3-78.

Plečkaitis, R. 2009. "The Rise of Philosophy in Lithuania", Studies in East European Thought 61(1): 3-13. doi:10.1007/s11212-008-9069-4

Sadowski, A. 2009. "The Borderland of Civilizations as a Research Category in the Sociology of Borderland“, Limes: Cultural Regionalistics 2(1): 82-92. doi:10.3846/2029-0187.2009.1.82-92

Бахтин, М. 2000. Автор и герой. Санкт-Петербург: Азбука. 
Бумблаускас, А. 2008. „Передмова“, в кн.: О. Русіна; I. Сварник; Л. Войтович (Ред.). Украӥна: Питовська доба 1320-1569. Київ: Балтія-Друк, 8-18.

Пашкоў, Г. П. (Ред.). 2007. Вялікае Княства Літоўскае. Т. 1. Мінск: Беларуская энцыклапедыя імя Петруся Броўкі.

Тойнби, А. Дж. 1991. Постижение истории. Москва: Прогресс.

\title{
KULTŪRINIS ITTERITORINIMAS: LIETUVOS DIDŽIOSIOS KUNIGAIKŠTYSTĖS ATVEJIS
}

\author{
Tomas Kačerauskas
}

\begin{abstract}
Santrauka
Straipsnyje plètojama iteritorinimo, išteritorinimo ir atiteritorinimo dialektika kultūrinès regionalistikos kontekste. Autorius parodo, kaip šie terra dinamikos modusai, keisdamiesi vaidmenimis, veikia kultūros kaip egzistencinès kūrybos tapsmą. Plètojant šias idejjas pasitelkiamas Lietuvos Didžiosios Kunigaikštystès (LDK) atvejis. Pasak autoriaus, turime reikalą su polifoniniu įteritorinimo procesu, kai fizinis aspektas yra kaip kultūrinio išteritorinimo fonas, ir atvirkščiai. Kultūrinès regionalistikos perspektyva suponuoja egzistencini požiūrị (kultūra kaip egzistencinè kūryba) ir ribų diskursą, ribą interpretuojant kaip kultūros reiškini, kultivuotiną tiek individo, tiek tautos. Didžioji tezė: gyvenamojo pasaulio ribų dinamika seka iš žmogaus egzistencinio kūrybingumo, kurio šaltinis - būtis myriop. Mažoji tezè: tauta gyva kaip terra individualiam (at)gimimui, individui kuriant būsimą bendriją savo veiklai. Autorius pristato dvejopą komunikaciją iteritorinimo metu: horizontalią, kuri turi reikalą su utopijos igyvendinimu, ir vertikalią, kuri turi reikalą su tautos praeities mitais. Vaidmenų kaita tarp skirtingų žmogaus terra aspektų žymi kultūros kaip kovos už kūrybinę erdvę ir egzistencinę teritoriją nelinijinę daugiasluoksnę raidą. Pasak autoriaus, atiteritorinimas suponuoja laikini aspektą, kuris apima visus tris modusus dẻ jų dialektikos. Istoriniai vaizdiniai vartojami mūsų politinejje terra ir, atvirkščiai, istorinès terrae suprantamos politinèje perspektyvoje.
\end{abstract}

Reikšminiai žodžiai: ịteritorinimo modusai, kultūrinė teritorija, istoriniai ịvaizdžiai, ribos, egzistencinė kūryba.

Received 29 January 2010, accepted 1 February 2010 